\title{
Effect of Feed Restriction on Carcass Yield Characteristics and Economic Advantages of Rhode Island Red Pullets
}

\author{
Etalem Tesfaye $^{1, *}$, Tadelle Dessie ${ }^{2}$, Dawud Ibrahim $^{3}$, Adey Melesse $^{3}$ \\ ${ }^{1,3}$ Ethiopian Institute of Agricultural Research, Debre Zeit Agricultural Research Center, , Debre Zeit, P.O.Box 32, Ethiopia \\ ${ }^{2}$ International Livestock Research Institute (ILRI), Addis Ababa, Ethiopia
}

\begin{abstract}
Carcass yield characteristics and economic advantage of skip-a-day feed restriction method at different growth stages of Rhode Island Red chicken was evaluated. Two-hundred forty day-old chicks with average body weight of $48.92 \pm 1.5$ $\mathrm{g}$ were randomly distributed into 12 pens each with 20 chicks, representing four feeding regimen of $\mathrm{T}_{1}$ (Unrestricted, Control), $\mathrm{T}_{2}$ (Restricted at 7, 14, 21 and 28 days of age), $\mathrm{T}_{3}$ (Restricted at 35, 42, 49 and 56 days of age) and $\mathrm{T}_{4}$ (Restricted at 63, 70, 77 and 84 days of age). Feed restriction was based on skipping a-day once in a week and the next day's feed offer was based on the previous day's feed intake. The experiment lasted for 22 weeks, during which feed intake and body weight changes were monitored. At the end of the experimental period, six pullets from each treatment were randomly selected and slaughtered to evaluate carcass yield, abdominal fat and weights and lengths of different parts of gastrointestinal tract. The daily DM, CP and ME intake as well as body weight changes at different ages were non-significant $(\mathrm{P}>0.05)$ for birds in different treatment groups. The DM efficiency ratio also did not significantly varied $(\mathrm{P}>0.05)$. In contrast, the total DM intake $(\mathrm{g})$ was significantly different $(\mathrm{P}<0.05)$ between treatments and birds under $\mathrm{T}_{4}$ consume less. Dressed weight $(\mathrm{g})(1335.45 \pm 21$, $1273.62 \pm 23.8,1335.78 \pm 22.8$ and $1279.72 \pm 23.4)$; abdominal fat free carcass (g) $(939.08 \pm 9.67,891.37 \pm 19.7,933.32 \pm 15$ and $899.07 \pm 14.5)$; carcass with abdominal fat (g) $(960.6 \pm 11.3,924.58 \pm 19,955.20 \pm 13$ and $926.10 \pm 14.4)$ and breast meat weights (g) $(282.72 \pm 13.7,246.75 \pm 19.8,290.70 \pm 13.4$ and $272.92 \pm 14.2)$ were significantly $(\mathrm{P}<0.05)$ different among the treatment groups. Abdominal fat weight was also highly significant $(\mathrm{P}<0.01)$ between the treatments. The weight and percentage of GIT and total giblet and parts of giblets were not $(\mathrm{P}>0.05)$ affected except liver weight which was higher $(\mathrm{P}<0.05)$ for $\mathrm{T}_{3}$. Cost of feed consumed per $\mathrm{kg}$ live weight gain was lower for the feed restricted birds compared to the control and it was the least for $\mathrm{T}_{4}$. Besides, the labor cost was lower for the feed restricted groups than the unrestricted group. It is concluded that feed restriction at later days of age $\left(T_{4}\right)$ is economically beneficial compared to the other early age restricted groups based on partial budget analysis. The results of this study suggested that the feed restriction at $\mathrm{T}_{3}$ might be considered as beneficial in terms of carcass cut characteristics and $\mathrm{T}_{4}$ on economic return.
\end{abstract}

Keywords Carcass Yield Characteristics, Economic Advantages, Feed Restriction, Skip A-Day, Rhode Island Red Pullet

\section{Introduction}

In commercial poultry production system profit can be maximized by minimizing feed cost which accounts for more than half of the total cost of production. Feed cost accounts for $60-70 \%$ of the cost of poultry production[1]. Any attempt to improve commercial poultry production and increase its efficiency therefore, needs to focus on better utilization of available feed resources[2]. One such method is restricting the amount of daily feed offer for sometime and stimulating compensatory growth[3-6].

* Corresponding author:

etalemtes@yahoo.com (Etalem Tesfaye)

Published online at http://journal.sapub.org/ijaf

Copyright $(\underset{2}{ } 2011$ Scientific \& Academic Publishing. All Rights Reserved
The use of total feed restriction at an early age to elicit compensatory growth, improved feed efficiency and reduced abdominal fat pad has received considerable attention. Researchers [3, 4] suggested that physical feed restriction at early age of birds for a short period stimulated compensatory growth so that at the market age feed restricted birds performed similarly to those of the full fed groups. Researchers[7,6] also reported that early period $75 \%$ ad libitum restriction feeding gave an economic advantage over ad libitum feeding mainly by enhancing feed utilization and able to attain complete live weight compensation by 42 days of age.

Even though a lot of work has been done on broilers on aspects of feed restriction, no information is available regarding the dual purpose breeds like Rhode Island Red (RIR) chicken and the effect of feed restriction on their carcass yield characteristics. Given the fact that the current extension 
program in Ethiopia focuses on distribution of exotic pullets to farm household's proper feeding management is important to attain better performance. Under quantitative feed restriction, the birds are not necessarily subjected to suboptimal level of nutrients, but the efficiency of utilization of these nutrients may be altered. This paper reports the effects of feed restriction at different growth stages on carcass yield and characteristics and economic advantages of Rhode Island Red chicken.

\section{Materials and Methods}

\subsection{Animals, Experimental Design and Treatments}

The experiment was conducted at poultry farm of Haramaya University, located at an altitude of 1980 m.a.s.1, 9 ${ }^{0} 26^{\prime} \mathrm{N}$ latitude and $42^{\circ} 3^{\prime} \mathrm{E}$ longitude[8]. A total of 240 day old chicks with an average body weight of $48.92 \pm 1.53 \mathrm{~g}$ were used for the feeding trial and were randomly assigned to the four feeding treatments $\left[\mathrm{T}_{1}\right.$ (Unrestricted, Control), $\mathrm{T}_{2}$ (Restricted at 7, 14, 21 and 28 days of age), $\mathrm{T}_{3}$ (Restricted at $35,42,49$ and 56 days of age) and $\mathrm{T}_{4}$ (Restricted at 63, 70, 77 and 84 days of age)] using a Completely Randomized Design (CRD).

\subsection{Feeds and Feeding}

Birds were fed on a commercial starter layer diet until the age of 6 weeks and on commercial grower layer diet till the end of the experiment (at age of 22 weeks). Feed was offered to the birds twice a day at 0800 and 1600 hours except at days of feed restriction for $T_{2}, T_{3}$ and $T_{4}$. Feed restriction was based on skipping a-day (restrict daily ration) once in a week, totally 4 days at different age of development for each treatment for the whole experimental period and the next day's feed offer was based on the previous day's feed intake. The feed restriction was done after the completion of one treatment then the other was followed $\left(T_{3}\right.$ started when $T_{2}$ was finished and then $\mathrm{T}_{4}$ was followed). On the feed restriction day only water was given. Feed wastage was controlled by filling the feed not more than $3 / 4^{\text {th }}$ of the feeder capacity.

\subsection{Measurements and Observations}

Birds were weighed per pen (replication) on weekly basis with sensitive balance of $0.005 \mathrm{~kg}$ to $3 \mathrm{~kg}$ capacity, and average body weight of the bird was computed using the weight of replications. The overall average body weight for each treatment was then computed by taking the average values for the replication. The daily as well as total feed consumption of the birds were calculated as the difference between the amount of feed offered and refused. Dry matter efficiency ratios (gain to intake) were also computed. To estimate the economic benefit of feed restriction in pullets rearing, the partial budget analyses was made taking into consideration the whole feed expense, labor cost and prices of live pullets at Haramaya University Poultry Farm based on the principles developed by[9], whereby other costs were assumed to be similar for all the treatments. The cost of labor considered during the experimental period was as needed $2 / 3^{\text {rd }}$ less on the days of feed restriction than the unrestricted days since only fresh water was offered at the days of restriction.

Partial production cost per live weight gain $=$ Cost of feed consumed (Birr) + Labor (Birr) Price of pullet (Birr)

At the end of the feeding trial (22 weeks), 6 randomly selected pullets from each treatment group were starved for 12 hours, and weighed immediately before slaughter. After slaughtering the birds were dry de-feathered by hand plucking, eviscerated and carcass cuts and non-edible offal components were determined according to the procedure described[10]. Dressed carcass weight was measured after the removal of blood and feather and the dressing percentage calculated as the proportion of dressed carcass weight to slaughter weight. Eviscerated carcass weight was determined after removing blood, feather, lower leg, head, kidney, lungs, pancreas, crop, proventriculus, small intestine, large intestine, caeca and urogenital tracts. The eviscerated carcass percentage was also calculated. Drumstick-thigh and breast meat were separated and weighed and percentage weights were determined.

Fat around the proventriculus and gizzard and against the abdominal wall and the cloacae was collected and weighed. Its percentage was calculated, the edible offal (giblets), which included the heart, gizzard and liver were weighed. The weight of crop, liver, gizzard, proventriculus, duodenum, jejunum and ileum, caeca and large intestine were weighed with and without contents. The relative weights were calculated as a proportion of weight of GIT parts to slaughter body weight. The lengths of the parts were measured by using centimeter tape. The weight of liver was also noted.

\subsection{Statistical Analysis}

Data were analysed using the General Linear Model (GLM) procedures of SAS[11]. The fixed effect fitted in the model included the effect of treatment (Control, $T_{2}, T_{3}$ and $\mathrm{T}_{4}$ ). Tukey Kramer test was used to separate means which were significant in the least squares analysis of variance[11]. The following model was used for the analysis.

$$
\begin{aligned}
& \mathrm{Y}_{\mathrm{ij}}=\mu+\mathrm{T}_{\mathrm{i}}+\mathrm{e}_{\mathrm{ij}} \\
& \text { Where, } Y_{\mathrm{ij}}=\text { an observation (experimental unit), } \\
& \mu=\text { overall mean feed restriction effect of } i^{\text {th }} \\
& \text { restriction level and, } \\
& \mathrm{e}_{\mathrm{ij}}=\text { error term }
\end{aligned}
$$

\section{Results and Discussion}

\subsection{Dry Matter and Nutrient Intake}

The laboratory chemical analysis results of feeds used in the experiment revealed the crude protein and energy contents of the commercial feeds of $20.22 \%$ and $3144 \mathrm{ME}$ $\mathrm{kcal} / \mathrm{kg} \mathrm{DM}$ for the starter diet and $18.52 \%$ and $2883 \mathrm{ME}$ 
$\mathrm{kcal} / \mathrm{kg} \mathrm{DM}$ for grower's layer feed offered, respectively. The $\mathrm{CP}$ and ME contents of the diets were within the range of the recommended $\mathrm{CP}$ and ME levels of starters and growers of $18 \%$ and $2950 \mathrm{ME} \mathrm{kcal} / \mathrm{kg}$ and $17 \%$ and 2850 $\mathrm{ME} \mathrm{kcal} / \mathrm{kg}$, respectively[12].

The feed restriction of skip-a-day program didn't result in a significant $(\mathrm{P}>0.05)$ difference in average daily DM intake, $\mathrm{CP}$ intake and ME intake between treatments including the control group (Table 1). The non-significant difference in daily feed intake between the control and treatment groups were not in agreement with the findings of $[13]$ who reported that intermittently fed group consumed considerably more on the following day than ad libitum fed chickens did.

The similarity in daily DM and nutrient intakes in the present experiment might be due to the fact that the amount of feed offered to birds on the next day was based on the previous day's feed intake of the control group. The total DM intake, however, were significantly $(\mathrm{P}<0.05)$ different between feed restricted and unrestricted groups and birds under $\mathrm{T}_{4}$ consumed less feed compared to the control group during the experimental period. The reason might be due to the fact that the feed restriction applied at later age and at the time the daily requirement was high reduced the total consumption than the other groups due to skipping days. The results obtained in the present experiment were similar to the findings of different researcher[5,7,6] who reported that significantly less feed was needed per unit of weight gain as did controls than after undergoing nutritional stress by consuming a diluted diet.

\subsection{Carcass Yield and Characteristics}

Least squares means and standard errors of the weight and proportion of eviscerated carcass components are presented in Table 2. The slaughter weight did not differ significantly $(\mathrm{P}>0.05)$ between the birds in the different stages of feed restriction and the control group. The analysis results of dressed weight, eviscerated carcass yield weight without abdominal fat as well as with abdominal fat and breast meat weight showed significant $(\mathrm{P}<0.05)$ differences between treatments. Among the feed restricted groups, $T_{3}$ had similar carcass yield with the control group and birds on $\mathrm{T}_{2}$ exhibited significantly $(\mathrm{P}<0.05)$ lower carcass yield compared to birds on the unrestricted feeding system. On the other hand, there was no significant difference between all treatments in dressing and eviscerated carcass percentages.

Abdominal fat free carcass of birds under $\mathrm{T}_{3}$ and $\mathrm{T}_{4}$ was similar with the control group (Table 2). Birds in $\mathrm{T}_{2}$ were the least in eviscerated carcass weight. The low carcass yield exhibited by the early age feed restricted group $\left(T_{2}\right)$ might be due to inefficient nutrient utilization and the subsequent poor tissue and fat deposition (growth) of birds at the age subjected to feed restriction. It might be due to distribution of energy resources among different organs during very early stages of development. Similarly,[14] stated that under-nutrition in the earlier stages of growth is more detrimental to an animal than is restricted at a later age.

Birds under $\mathrm{T}_{2}$ exhibited significantly $(\mathrm{P}<0.01)$ less drumstick-thigh weights than birds on $\mathrm{T}_{3}$ and the control group. Even though drumstick-thigh percentage increased with feed restricted group, there was no significant $(\mathrm{P}>0.05)$ difference among the treatments. The higher drumstick-thigh weight for $\mathrm{T}_{3}$ might be due to compensatory growth for the group.

Table 1. Least squares means ( \pm SE) for dry matter intake, body weight change and DM efficiency ratio as affected by feed restriction on different developmental stages.

\begin{tabular}{|c|c|c|c|c|c|}
\hline \multirow{2}{*}{ Parameters } & \multicolumn{5}{|c|}{ Treatments } \\
\hline & $\mathrm{T}_{1}$ & $\mathrm{~T}_{2}$ & $\mathrm{~T}_{3}$ & $\mathrm{~T}_{4}$ & F-test \\
\hline Daily DM intake (g) & $70.54 \pm 3.20$ & $66.68 \pm 3.10$ & $68.33 \pm 1.30$ & $64.69 \pm 3.80$ & NS \\
\hline Total DM intake $(\mathrm{kg})$ & $11.17^{\mathrm{a}} \pm 0.50$ & $10.56^{\mathrm{ab}} \pm 0.50$ & $10.82^{\mathrm{ab}} \pm 0.20$ & $9.97^{\mathrm{b}} \pm 0.30$ & $*$ \\
\hline Daily CP intake (g) & $15.8 \pm 0.72$ & $15.93 \pm 0.70$ & $15.30 \pm 0.30$ & $14.48 \pm 0.85$ & NS \\
\hline Daily ME intake (kcal) & $2055.36 \pm 170.60$ & $2194.37 \pm 97.90$ & $2045.79 \pm 132.90$ & $2033.76 \pm 116.90$ & NS \\
\hline Initial BW (g) & $48.51 \pm 0.30$ & $48.48 \pm 0.80$ & $49.03 \pm 0.70$ & $49.65 \pm 1$ & NS \\
\hline Daily BW gain(g) & $8.933 \pm 0.20$ & $8.967 \pm 0.60$ & $9.133 \pm 1.20$ & $9.067 \pm 0.60$ & NS \\
\hline Final BW (g) & $1433 \pm 82.20$ & $1438 \pm 95.00$ & $1464 \pm 89.30$ & $1451 \pm 92.30$ & NS \\
\hline DM efficiency ratio & $0.124 \pm 0.50$ & $0.131 \pm 0.40$ & $0.131 \pm 0.30$ & $0.141 \pm 0.50$ & NS \\
\hline
\end{tabular}

$\mathrm{BW}=$ body weight; Initial BW $(\mathrm{g})=$ at 7 -day old, Final $\mathrm{BW}=$ at 22 weeks old, $*=$ Significant at $\mathrm{P}<0.05$, NS $=$ Non-significant, $\mathrm{SE}=\mathrm{Standard}$ Error 
Table 2. Least squares means ( $\pm \mathrm{SE})$ for carcass components as affected by feed restriction.

\begin{tabular}{|c|c|c|c|c|c|}
\hline \multirow{2}{*}{ Parameters } & \multicolumn{5}{|c|}{ Treatments } \\
\hline & $\mathrm{T}_{1}$ & $\mathrm{~T}_{2}$ & $\mathrm{~T}_{3}$ & $\mathrm{~T}_{4}$ & P-value \\
\hline Slaughter weight (g) & $1430.43 \pm 33.70$ & $1436.55 \pm 46.4$ & $1461.65 \pm 32.30$ & $1443.62 \pm 18.20$ & NS \\
\hline Dressed weight & $1335.45 \pm 21^{\mathrm{a}}$ & $1273.62 \pm 23.8^{\mathrm{b}}$ & $1335.78 \pm 22.80^{\mathrm{a}}$ & $1279.72 \pm 23.40^{\mathrm{b}}$ & * \\
\hline Dressing percentage & $87.33 \pm 4.17$ & $88.94 \pm 6.6$ & $92.47 \pm 7.01$ & $88.94 \pm 6.74$ & NS \\
\hline Carcass with abdominal fat (g) & $960.60 \pm 11.30^{\mathrm{a}}$ & $924.58 \pm 19^{b}$ & $955.20 \pm 13^{\mathrm{a}}$ & $926.10 \pm 14.40^{\mathrm{b}}$ & $*$ \\
\hline Carcass with abdominal fat (\%) & $67.15 \pm 0.70$ & $64.38 \pm 1.36$ & $65.36 \pm 1.25$ & $64.16 \pm 1.43$ & NS \\
\hline Abdominal fat free carcass (g) & $939.08 \pm 9.67^{\mathrm{a}}$ & $891.37 \pm 19.7^{\mathrm{b}}$ & $933.32 \pm 15^{\mathrm{a}}$ & $899.07 \pm 14.50^{\mathrm{ab}}$ & $*$ \\
\hline Abdominal fat free carcass (\%) & $65.65 \pm 0.60$ & $62.07 \pm 1.33$ & $63.86 \pm 1.20$ & $62.29 \pm 1.40$ & NS \\
\hline Drumstick-thigh weight (g) & $238.33 \pm 3.51^{\mathrm{a}}$ & $226.33 \pm 2.08^{b}$ & $239.67 \pm 2.52^{\mathrm{a}}$ & $235.33 \pm 5.03^{\mathrm{ab}}$ & $* *$ \\
\hline Drumstick-thigh weight (\%) & $16.66 \pm 0.54$ & $15.81 \pm 1.14$ & $16.60 \pm 2.39$ & $16.33 \pm 0.75$ & NS \\
\hline Breast meat weight (g) & $282.72 \pm 13.70^{\mathrm{a}}$ & $246.75 \pm 19.8^{b}$ & $290.70 \pm 13.40^{\mathrm{a}}$ & $272.92 \pm 14.20^{\mathrm{ab}}$ & $*$ \\
\hline Breast meat weight (\%) & $19.76 \pm 0.88$ & $17.20 \pm 1.66$ & $19.90 \pm 1.22$ & $18.91 \pm 1.15$ & NS \\
\hline Abdominal fat weight (g) & $25.33 \pm 1.53^{\mathrm{b}}$ & $33.23 \pm 0.81^{\mathrm{a}}$ & $21.90 \pm 2.09^{b}$ & $24.17 \pm 1.26^{\mathrm{b}}$ & $* *$ \\
\hline Abdominal fat (\%) & $1.77 \pm 0.08^{\mathrm{b}}$ & $2.32 \pm 0.13^{\mathrm{a}}$ & $1.51 \pm 0.15^{\mathrm{b}}$ & $1.68 \pm 0.15^{\mathrm{b}}$ & $* *$ \\
\hline Feather weight (g) & $108.53 \pm 7.11$ & $116.55 \pm 6.19$ & $119.33 \pm 3.77$ & $116.37 \pm 6.08$ & NS \\
\hline Leg length $(\mathrm{cm})$ & $13.83 \pm 0.63$ & $14.42 \pm 0.76$ & $14.08 \pm 0.14$ & $14 \pm 0.50$ & NS \\
\hline
\end{tabular}

Slaughter weight $(\mathrm{g})=$ at 22 weeks old, Least squares means within a row with different superscripts are significantly different; * =Significant at $\mathrm{P}<0.05 ; \mathrm{NS}=$ Non-significant, $\mathrm{SE}=$ standard Error

Eviscerated carcass and breast meat weight did vary significantly $(\mathrm{P}<0.05)$ between treatments and it was lower for $\mathrm{T}_{2}$. The increase in breast meat weight with the late age initiated feed restrictions groups might be due to attainment of maximum bone and feather development at early age before feed restriction starts. Earlier age $\left(\mathrm{T}_{2}\right)$ initiated feed restrictions resulted in little evidence of compensatory growth, likely because of partition of nutrients primarily for formation of bone, muscle and adipose tissue[7] observed no effect on any of the carcass traits of both male and female broiler chickens at 21 days of age which was not in agreement with the present findings.

The analysis of abdominal fat weight showed a significant $(\mathrm{P}<0.01)$ difference among treatment groups. Birds on the restriction feeding system $T_{3}$ and $T_{4}$ accumulated similar amounts of abdominal fat with the unrestricted group and it was higher for birds feed restricted at earlier age $\left(\mathrm{T}_{2}\right)$. The results of $[15,16,6]$ virtually indicated no change in absolute quantity of abdominal fat in 42 to 49 days old broiler chicks subjected to feed restriction from 35 to 39 days of age. However, findings of investigators [17, 18] revealed that body fat was depressed when chickens were exposed to feed restriction. Inconsistently[19] observed an increased level of abdominal fat percent with advancing slaughter age.

In the present study, the feed restriction method did not affect $(\mathrm{P}>0.05)$ the feather weight and leg length (Table 2). The results were in agreement with the findings of[16], who reported a non negative effect of feeding regimen on weights of legs and feather.

\subsection{Giblet Weight and Percentage}

The edible offal (giblets) except liver was not significantly $(\mathrm{P}>0.05)$ different in feed restricted and free accessed group of birds (Table 3 ). Birds on control and feed restricted groups had similar $(\mathrm{P}>0.05)$ gizzard and heart weights and percentages. However, weight of liver was different between the groups. Pullets reared under $\mathrm{T}_{3}$ had significantly $(\mathrm{P}<0.05)$ heavier liver weight and there was no significant $(\mathrm{P}>0.05)$ difference on liver percentage among the pullets reared on feed restriction and the unrestricted feeding regimen. The increase in liver weight was due to effective synthesis of available energy to lipid for egg yolk formation during the re-feeding time. 
Table 3. Least squares means ( \pm SE) for average giblet weight $(\mathrm{g})$ and percentages $(\%)$ as affected by feed restriction.

\begin{tabular}{|c|c|c|c|c|c|c|}
\hline \multirow{2}{*}{\multicolumn{2}{|c|}{ Parameters }} & \multicolumn{5}{|c|}{ Treatments } \\
\hline & & $\mathrm{T}_{1}$ & $\mathrm{~T}_{2}$ & $\mathrm{~T}_{3}$ & $\mathrm{~T}_{4}$ & P-value \\
\hline \multirow{2}{*}{ Giblet } & Weight & $94.82 \pm 4.60$ & $97.87 \pm 4.00$ & $89.12 \pm 3.20$ & $90.48 \pm 6.2$ & NS \\
\hline & Percent & $6.19 \pm 0.25$ & $6.82 \pm 0.83$ & $6.15 \pm 0.63$ & $6.27 \pm 0.35$ & NS \\
\hline \multirow{2}{*}{ Gizzard } & Weight & $32.22 \pm 1.40$ & $33.48 \pm 2.60$ & $32.37 \pm 2.20$ & $32.12 \pm 3.9$ & NS \\
\hline & Percent & $2.96 \pm 0.15$ & $3.50 \pm 0.81$ & $3.16 \pm 0.32$ & $3.33 \pm 0.57$ & NS \\
\hline \multirow{2}{*}{ Heart } & Weight & $9.53 \pm 0.41$ & $8.35 \pm 0.48$ & $8.18 \pm 0.68$ & $8.48 \pm 0.89$ & NS \\
\hline & Percent & $0.59 \pm 0.05$ & $0.64 \pm 0.04$ & $0.56 \pm 0.09$ & $0.55 \pm 0.07$ & NS \\
\hline \multirow{2}{*}{ Liver } & Weight & $35.80 \pm .57^{\mathrm{b}}$ & $5.50 \pm 0.87^{b}$ & $39.70 \pm 1.21^{\mathrm{a}}$ & $36.17 \pm 2.50^{b}$ & $*$ \\
\hline & Percent & $2.34 \pm 0.19$ & $2.48 \pm 0.22$ & $2.75 \pm 0.32$ & $2.52 \pm 0.33$ & NS \\
\hline
\end{tabular}

Least squares means within a row with different superscripts are significantly different; * $=\mathrm{P}<0.05$, NS=Non-significant, $\mathrm{SE}=$ standard Error

The present findings were not in agreement with results of[20] who reported a non-significant difference in the mean values of the liver among the treatment groups due to any feed restriction program when compared to those of control group.[21] found that intermittent feeding was accompanied by a consistent increase in the relative weight of the liver. Similar to the present findings[16,22] reported a non significant difference in relative weights of liver at slaughter due to the feeding regimen.

\subsection{Weight and Length of Gastrointestinal Tract}

There was no significant $(\mathrm{P}>0.05)$ difference in weight, length and percent of most gastrointestinal tract (GIT) parts among the treatment groups (Table 4). Duodenum and ileum empty weight $(\mathrm{P}<0.05)$, large intestine empty weight $(\mathrm{P}<0.01)$ and large intestine length $(\mathrm{P}<0.05)$ were significantly different between treatments.

Table 4. Least squares means ( \pm SE) for treatments on the empty weight and length of gastrointestinal tract

\begin{tabular}{|c|c|c|c|c|c|}
\hline \multirow[t]{2}{*}{ Parts of GIT } & \multicolumn{5}{|c|}{ Treatments } \\
\hline & $\mathrm{T}_{1}$ & $\mathrm{~T}_{2}$ & $\mathrm{~T}_{3}$ & $\mathrm{~T}_{4}$ & P-value \\
\hline Esophagus(g) & $6.55 \pm 0.43$ & $4.90 \pm 0.22$ & $5.35 \pm 0.56$ & $6.08 \pm 0.38$ & NS \\
\hline Esophagus(cm) & $11.30 \pm 1.15$ & $8.25 \pm 1.15$ & $10.58 \pm 3.20$ & $11.75 \pm 1.20$ & NS \\
\hline Crop (g) & $6.18 \pm 0.88$ & $5.70 \pm 0.70$ & $5.08 \pm 0.46$ & $5.45 \pm 0.67$ & NS \\
\hline Crop (cm) & $4.58 \pm 0.52$ & $4.33 \pm 0.48$ & $5.28 \pm 0.40$ & $5.25 \pm 0.75$ & NS \\
\hline Proventriculus(g) & $6.80 \pm 0.58$ & $6.38 \pm 0.68$ & $7.08 \pm 0.20$ & $6.43 \pm 0.43$ & NS \\
\hline Proventriculus (cm) & $3.92 \pm 0.76$ & $4.37 \pm 0.66$ & $4.63 \pm 0.32$ & $4.05 \pm 0.18$ & NS \\
\hline Gizzard (g) & $32.22 \pm 1.40$ & $33.48 \pm 5$ & $32.37 \pm 2$ & $32.12 \pm 4$ & NS \\
\hline Gizzard (cm) & $19.10 \pm 0.38$ & $18.83 \pm 2.90$ & $18.67 \pm 2.50$ & $18.75 \pm 1.90$ & NS \\
\hline Duodenum (g) & $9.10 \pm 1.40^{\mathrm{ab}}$ & $9.43 \pm 1.40^{\mathrm{a}}$ & $7.43 \pm 0.30^{\mathrm{b}}$ & $7.8 \pm 0.20^{\mathrm{ab}}$ & $*$ \\
\hline Duodenum (cm) & $27.92 \pm 4.10$ & $26.30 \pm 3.38$ & $25.75 \pm 0.50$ & $26.42 \pm 2.10$ & NS \\
\hline Jejunum (g) & $20.57 \pm 2.40$ & $23.60 \pm 4.68$ & $20.57 \pm 3.80$ & $18.87 \pm 2.80$ & NS \\
\hline Jejunum (cm) & $66.10 \pm 2.98$ & $76.80 \pm 1.04$ & $77.67 \pm 2.10$ & $65.1 \pm 8.98$ & NS \\
\hline Ileum (g) & $8.10 \pm 0.90^{\mathrm{ab}}$ & $8.68 \pm 1.60^{\mathrm{ab}}$ & $6.9 \pm 0.43^{b}$ & $9.5 \pm 0.87^{\mathrm{a}}$ & $*$ \\
\hline Ileum (cm) & $32.52 \pm 2.30$ & $35.40 \pm 0.95$ & $30 \pm 2.22$ & $37.17 \pm 2.90$ & NS \\
\hline Caeca (g) & $7.75 \pm 0.17$ & $7.20 \pm 0.26$ & $6.98 \pm 0.32$ & $7.3 \pm 0.98$ & NS \\
\hline Caeca $(\mathrm{cm})$ & $19.5 \pm 20$ & $18.10 \pm 20$ & $18.75 \pm 2.30$ & $18.5 \pm 2.20$ & NS \\
\hline Large Intestine (g) & $3.12 \pm 0.10^{\mathrm{a}}$ & $3.18 \pm 0.18^{\mathrm{a}}$ & $2.9 \pm 0.03^{\mathrm{a}}$ & $2.6 \pm 0.12^{\mathrm{b}}$ & $* *$ \\
\hline Large Intestine $(\mathrm{cm})$ & $6.80 \pm 0.14^{\mathrm{a}}$ & $6.88 \pm 0.20^{\mathrm{a}}$ & $6.97 \pm 0.20^{\mathrm{a}}$ & $6.3 \pm 0.38^{\mathrm{b}}$ & $*$ \\
\hline
\end{tabular}

Least squares means within a row with different superscripts are significantly different; $* *=\mathrm{P}<0.01 ; *=\mathrm{P}<0.05 ; \mathrm{NS}=$ Non-significant, $\mathrm{SE}=$ standard Error 
The empty weight of duodenum and ileum were large for birds feed restricted at the earlier age $\left(\mathrm{T}_{2}\right)$ followed by the control and birds treated at later age $\left(\mathrm{T}_{4}\right)$. The difference in empty weight of duodenum and ileum (parts of small intestine) was difficult to relate with the feed restriction, but it seems probable that growth of the digestive tract during the critical period of feed restriction was preferentially retained above that of the demand organs. This selective maintenance of growth of the digestive tract could have contributed to the ability of the birds to achieve compensatory growth following food restriction by improving efficiency of the digestive process. However, many of the other parts were non significant $(\mathrm{P}>0.05)$. The lack of significant difference in most GIT parts empty weight and length reflected the fact that the feed restriction did not result in extension of the parts during re-feeding that could have accumulated more feed in the GIT. The probable reason again might be the fact that the amount of feed offered during non-restricted period was based on the previous day feed intake. Results in this study agree with the findings of[7] who reported that level of feed restriction caused a non-significant increase in the size of digestive organs concerned.

The weight $(\mathrm{P}<0.01)$ and length $(\mathrm{P}<0.05)$ of large intestine were significantly lower for $\mathrm{T}_{4}$ for which no plausible justification could be found from available literature to favor or disfavour[16,22] indicated non significant difference in organ weight (heart and lungs) at slaughter which was in line with the present results. In addition, the later also reported similar result to the present findings with regard to the lack of difference between the restricted and ad libitum fed birds in weights of the gizzard and proventriculus. Others[23,24,5], however, did obtain a significant increase in gizzard weight and reduction in relative weight of the heart at 56 days of age following short term restriction.

Table 5. Partial budgeting for effects of feed restriction on net benefit from pullets rearing

\begin{tabular}{ccccc}
\hline Items & $\mathrm{T}_{1}$ & $\mathrm{~T}_{2}$ & $\mathrm{~T}_{3}$ & $\mathrm{~T}_{4}$ \\
\hline $\begin{array}{c}\text { Cost of feed con- } \\
\text { sumed (Birr) }\end{array}$ & 18.786 & 17.752 & 18.197 & 17.245 \\
$\begin{array}{c}\text { Total feed consumed } \\
(\mathrm{kg})\end{array}$ & 11.173 & 10.563 & 10.823 & 10.247 \\
$\begin{array}{c}\text { Cost of feed/kg } \\
\text { TBWG (Birr) }\end{array}$ & 14.96 & 13.40 & 13.97 & 12.51 \\
$\begin{array}{c}\text { Labor cost } \\
\text { (Birr) }\end{array}$ & 3.969 & 3.861 & 3.861 & 3.861 \\
$\begin{array}{c}\text { Live pullets sale } \\
\quad(\text { Birr) }\end{array}$ & 25.00 & 25.00 & 25.00 & 25.00 \\
$\begin{array}{c}\text { Live pullets sale/feed } \\
\text { cost }\end{array}$ & 1.33 & 1.41 & 1.37 & 1.45 \\
\hline Total Profit (Birr) & 2.245 & 3.387 & 2.942 & 3.894 \\
\hline
\end{tabular}

$* \mathrm{TBWG}=$ Total Body Weight Gain, ${ }^{1}=0.027 \mathrm{Birr} / \mathrm{bird} /$ day and $1 / 3^{\text {rd }}$ needed on the days of feed restriction for the feed restricted birds,total feed consumed $=154$ days

\subsection{Economic Considerations}

The economic return based on the partial budget analysis results from pullets reared under different feed restrictions is presented in Table 5. The highest net benefits of 1.65 Birr per bird was obtained from the sale of pullets reared under the feeding regimen of feed restriction $\left(\mathrm{T}_{4}\right)$ as compared to birds that were not restricted. The net benefit obtained decreased with birds under $T_{3}$ and better for birds under treatment $T_{2}$ and least for the control group. The better performance of birds which were under $\mathrm{T}_{4}$ might be due to the fact that feed restriction at this age group might not affect body growth as birds accumulated enough reserves in the earlier periods. Similarly[6] reported that level of feed restriction caused some economic advantage over ad libitum feeding mainly by enhancing feed utilization. Contrary to the present findings, [25] noted non-significant different on feed restriction on cost of feed/dozen eggs during the laying phase.

\section{Conclusions}

In conclusion, depending on carcass cuts basis, feed restriction by skip-a-day feeding system at medium age $\left(\mathrm{T}_{3}\right)$ attains better performance and feeding system at later age of development $\left(\mathrm{T}_{4}\right)$ resulted in low feed consumption and better net benefit of pullet rearing and these can be considered as the optimum age to apply feed restriction accordingly. Future work may also address the incorporation of additional days on skip-a-day feeding system by increasing the total days either twice per week or more to obtain better performance on pullet rearing without affecting the bird's production performance.

\section{ACKNOWLEDGEMENTS}

We are greatly indebted to Ethiopian Institute of Agricultural Research (EIAR) and Haramaya University for funding the research work.

\section{REFERENCES}

[1] K. J. Wilson, and R. S. Beyer. (2000) Poultry nutrition information for the small flock. Kansas State University Agricultural Experiment Station and Cooperative Extension Service. $\underline{\text { htp: }: / / w w w . o z n e t . k s u . e d u}$

[2] DZARC. (1997) Debre Zeit Agricultural Research Center. Annual research report 1996/1997; Debre Zeit, Ethiopia. 86p

[3] Ibrahim, I.K. and S.S. Al-Taleb, 2002. The relationship between feed restriction at an early age and the occurrence of compensatory growth in light hybrid chickens. Mutah Lil Buhuth wad-Dirasat, 17(2):27-37

[4] Naji, S.A., I.A. Al-Ani, J.K. Manati and S.A. Mukhlis, 2003. Effect of early feed restriction on growth, feed conversion and mortality in broiler chickens. Proc. $5^{\text {th }}$ Con. Agric. Res., Feb. $22-24^{\text {th }}$, Mosul, University, Mosul, Iraq

[5] Al-Talib,S., 2007. Effect of nutrient intake restrictions by dietary dilutions with sand on broiler performance. Jordan J. 
Agr. Sci., 3 (3)

[6] Novele, D.J., J.W. Ng'Ambi, D. Norris and C.A. Mbajiorgu, 2009. Effect of different feed restriction regimes during the starter stage on productivity and carcass characteristics of male and female Ross 308 broiler chickens. International Journal of Poultry Sci., 8 (1): 35-39

[7] Novele, D.J., J.W. Ng'Ambi, D. Norris and C.A. Mbajiorgu, 2008. Effect of sex, level and period of feed restriction during the starter stage on productivity and carcass characteristics of Ross 308 broiler chickens in South Africa. International Journal of Poultry Sci. 7 (6): 530-537

[8] AUA. (1998) Alemaya University of Agriculture. pp. 29-30. Proceedings of the $15^{\text {th }}$ annual research and extension review meeting, 2 April 1998; Alemaya, Ethiopia

[9] M. Upton. (1979) Farm Management in Africa: The principle of production and planning. Oxford University Press, Great Britain. pp. 282-298

[10] C. C. Kekeocha. (1985) Introduction to poultry keeping. pp. 1-15.In: Poultry production hand book, Pfizer Corporation, Nairobi

[11] SAS. (2002) Statistical analysis systems for mixed models. SAS Institute Inc., Cary, NC, USA

[12] S. Leeson, and J. D. Summers, The nutrition of chicken. $4^{\text {th }}$ ed., university books, Canada. 591p, 2001

[13] Dunnington, E. A., Gross, W. B. and Siegel, P. B. 1992. Restricted feeding and broiler performance: age initiation and length of restriction. J. Poultry Sci., 71: 440-447

[14] Zubair, A. K., 1994. Compensatory growth in the broiler chicken. PhD Dissertation, University of Guelph, Guelph, Ontario. 129p

[15] Leeson, S., Summers, J. D. and Caston, L. J. 1992. Response of broilers of feed restriction or diet dilution in the finisher period. J. Poultry Sci., 71: 2056-2064

[16] Susbilla, P., Frankel, T. L., Parkinson, G. and Gow, C. B.
1994. Weight of internal organs and carcass yield of early food restricted broilers. British J. Poultry Sci., 35: 677-685

[17] Plavink, I. and Hurwitz, S. 1985. The performance of broiler chicks during and following a severe feed restriction at an early age. J. Poultry Sci., 64: 348-355

[18] Jones, G. P. D. and D. J. Ferrel, 1992. Early life food restriction of broiler chickens. II. Effect of food restriction on the development of fat tissues. British Poultry Sci., 33:589-601

[19] Mansour, K. M., Siam, S. S. and Osman, A. M. R. 2004. Effects of age and quantitative feed restriction prior to slaughtering on the performance, carcass characteristics and some blood constituents of broilers. Egyptian J. Poultry Sci., 24: 509-522

[20] Mahmood, S., S. Mehmood, F. Ahmad, A. Masood and R. Kausar, 2007. Effects of feed restriction during starter phase on subsequent growth performance, dressing percentage, relative organ weights and immune response of broilers. Pakistan J. Vet., 27 (3): 137-141

[21] Pinchasove, Y., Nir, I. and Nitsan, Z. 1985. Metabolic and anatomical adaptation of heavy bodied chickens to intermittent feeding. Food intake, growth rate, organ weight, and body Composition. J. Poultry Sci., 64: 2098-2109

[22] Jones, G. P. D. 1995. Manipulation of organ growth by early life food restriction: it's influence on the development of ascites in broiler chicken. British Poultry Sci., 36:135-142

[23] Plavink, I. and Hurwitz, S. 1983. Organ weights and body composition in chickens as related to the energy and amino acid requirements: effect on strain, sex and age. J. Poultry Sci., 62: $152-163$

[24] Katanbaf, M. N., Dunnington, E. A. and Siegel, P. B. 1989. Restricted feeding in early and late feathering chickens on organ size and carcass composition. J. Poultry Sci., 68: 359-368

[25] Sahota A. W. and B. M. Bhatti, 2001. Effect of feed restriction during growing period on laying performance of white leghorn hens. Pakistan J. Vet., 21(3): 145-147 